\title{
PENERAPAN MODEL GUIDED INQUIRY LEARNING DIPADU DENGAN CONCEPT MAP UNTUK MENINGKATKAN KEMAMPUAN BERPIKIR ANALITIS SISWA KELAS X-6 SMA NEGERI KEBAKKRAMAT
}

\section{IMPLEMENTATION OF GUIDED INQUIRY LEARNING COMBINED WITH CONCEPT MAPTO IMPROVE ANALYTICAL THINKING OF X-6 STUDENTS SMA NEGERI KEBAKKRAMAT}

\author{
SETYA MAULANI ${ }^{1}$, MURNI RAMLI ${ }^{1)}$, DEWI PUSPITA SARI ${ }^{1)}$, PRIYADI DWI PARWANTO ${ }^{2)}$ \\ 1)Program Studi Pendidikan Biologi \\ Fakultas Keguruan dan Ilmu Pendidikan \\ Universitas Sebelas Maret \\ J1. Ir. Sutami 36 A, Surakarta, 57126, Indonesia \\ *Corresponding Author: setyamaulani@gmail.com \\ 2) SMA Negeri Kebakkramat, Jawa Tengah Indonesia
}

Manuscript received : 11 Januari 2016 Revision accepted: 22 Maret 2016

\begin{abstract}
The purpose of this research is to increase the analytical thinking of X-6 students of SMA Negeri Kebakkramat by using guided inquiry learning model combined with concept map. This research is classroom action research execute in 3 cycles. Each cycles consist of 4 stages, the 4 stages is scheming, implementation, observation and reflection. The procedure of this research use Kemmis and Mc Taggart method. The subject of this research is X-6 students of SMA Negeri Kebakkramat school year 20014/2015 which amounts to 34 students consist 8 boys students and 26 girls students. This data of this research be obtained by using analytical thinking observation method, analytical thinking test, interview and documentation. This results of this research by using guided inquiry learning combined with concept map shows increase analytical thinking X-6 students of SMA Negeri Kebakramat from pra cycle, cycle I, cycle II and cycle III. The overall score the analytical thinking increase from 4,88 (40,69\%) become 7,31 (60,91\%). Differentiating aspect increase from 1,32 (47,79\%) become 2,28 (56,99\%), organizing aspect increase from $1,91(47,79 \%)$ become $2,87(71,69 \%)$ and attributing aspect increase from 1,65 (41,18\%) become 2,16 (54,04\%). Based on result of this research by using guided inquiry learning combined with concept map can increase the analytical thinking of X-6 students SMA Negeri Kebakkramat.
\end{abstract}

Keywords: guided inquiry learning, concept map, analytical thinking ability

\section{PENDAHULUAN}

Pada abad ke-21 ini, pendidikan di Indonesia saat ini sedang mengalami perubahan paradigma. Perubahan paradigma tersebut bertujuan untuk memberikan bekal kompetensi yang memadai bagi peserta didik, baik untuk studi lanjut maupun memasuki dunia kerja. Saat ini lapangan kerja lebih menuntut kemampuan menganalisis daripada kemampuan prosedural ataupun mekanistis (Rohana, et al., 2009). Dengan melatihkan peserta didik untuk berpikir analitis dapat menyebabkan siswa mempunyai kemampuan berpikir kritis dalam memecahkan suatu permasalahan yang dihadapi. Kemampuan berpikir analitis sangat diperlukan sebab ketika menghadapi perkembangan jaman, manusia diharapkan mampu berpikir analitis untuk menyelesaikan permasalahan yang ada, baik dalam dirinya, lingkungan sekitar, dan khususnya lingkungan sekolah (Purwito, et al., 2013).
Dalam proses pembelajaran, salah satu cara berpikir analitis adalah dengan menganalisis suatu permasalahan. Menganalisis meliputi proses memilah, mengorganisasi, dan mengatribusi. Memilah adalah menentukan bagian-bagian informasi yang relevan. Mengorganisasi adalah membangun bagian-bagian informasi secara sistematis dan koheren. Mengatribusi adalah menentukan tujuan dari informasi (Anderson \& Krathwohl, 2010).

Hasil observasi yang dilakukan terhadap pembelajaran Biologi di Kelas X-6 SMA Negeri Kebakkramat semester I tahun ajaran 2014/2015 menunjukkan bahwa skor kemampuan berpikir analitis sebesar 4,88 (40,69\%). Kemampuan siswa dalam memilah sebesar $1,32 \quad(33,09 \%)$, mengorganisasi sebesar 1,91 (47,79), serta mengatribusi sebesar 1,65 $(41,18 \%)$.

Hasil observasi di atas diperkuat dengan melakukan pengambilan data menggunakan 
wawancara kepada guru dan siswa. Hasil pengambilan data menunjukkan bahwa siswa masih kesulitan dalam melakukan pemilahan bagian yang penting dan kurang penting dalam sebuah konsep, menentukan tujuan dari sebuah informasi, serta membangun hubungan antara konsep satu dengan konsep yang lain. Kesulitan tersebut disebabkan karena siswa jarang berlatih untuk melakukan pemilahan bagian-bagian yang relevan, menentukan tujuan informasi dan membangun hubungan antarkonsep dalam proses pembelajaran Biologi di sekolah.

Hasil observasi dan wawancara menunjukkan bahwa proses pembelajaran di Kelas X6 SMA Negeri Kebakkramat kurang melatihkan kemampuan berpikir analitis. Metode dan model yang digunakan dalam proses pembelajaran Biologi hanya sekedar diskusi tanpa memberi latihan kepada siswa untuk berpikir analitis. Berpikir analitis di dalam proses pembelajaran dapat dilatihkan dengan melakukan kegiatan analisis terhadap suatu permasalahan. Proses pembelajaran yang dapat melibatkan banyak kegiatan menganalisis salah satunya melalui model guided inquiry learning. Model ini menekankan proses investigasi terhadap permasalahan dengan dibimbing oleh guru. Model guided inquiry learning merupakan aplikasi dari pembelajaran konstruktivisme yang didasarkan pada observasi dan studi ilmiah (Nurtafita, 2011). Model guided inquiry learning ditempuh dengan menerapkan lima langkah kegiatan pembelajaran menurut Eggen dan Kauchack dalam Amri \& Ahmadi (2010), yaitu merumuskan pertanyaan atau permasalahan, merumuskan hipotesis, mengumpulkan data, menguji hipotesis, dan membuat kesimpulan.

Hasil observasi dan wawancara terhadap siswa Kelas X-6 SMA Negeri Kebakkramat menunjukkan bahwa mereka belum pernah membuat peta konsep. Untuk memudahkan siswa memahami konsep secara utuh pada pembelajaran Biologi maka model guided inquiry learning dipadukan dengan concept map. Concept map merupakan urutan secara hirarkis antara satu konsep dengan konsep lain, mulai dari konsep paling inklusif ke konsep yang lebih khusus dan menunjukkan hubungan yang bermakna (Warsono \& Hariyanto, 2013). Selain itu, peta konsep bertujuan untuk merefleksikan kemampuan berpikir siswa (Sujana, 2009). Sehingga penggunaan peta konsep sangat dianjurkan dalam rangka mengembangkan kemampuan berpikir analitis siswa.

\section{METODE PENELITIAN}

Penelitian ini dilaksanakan di kelas X-6 SMA Kebakkramat Semester II Tahun Pelajaran 2014/2015. Pelaksanaan penelitian dibagi menjadi tiga tahap, yaitu: tahap persiapan, penelitian, dan penyelesaian. Penelitian tindakan kelas ini dilakukan selama tiga siklus dari tanggal 6 Mei 2015 sampai 21 Mei 2015 dengan subjek penelitian yaitu siswa kelas X-6 SMA Negeri Kebakkramat Tahun Pelajaran 2014/2015. Sebelum dilaksanakan penelitian dilakukan observasi awal sebagai dasar kemampuan berpikir analitis siswa. Penilaian kemampuan berpikir analitis dilakukan setiap akhir siklus untuk mengukur peningkatan kemampuan berpikir analitis siswa setelah diterapkan pembelajaran dengan model guided inquiry learning.

Pengumpulan data kemampuan berpikir analitis dilakukan dengan teknik tes dan non tes. Teknik tes dilakukan dengan memberikan tes tertulis di setiap akhir siklus, sedangkan teknik non tes dilakukan dengan lembar observasi kemampuan berpikir analitis, wawancara, observasi, dan dokumentasi yang dilakukan saat proses pembelajaran. Teknik validitas data yang digunakan dalam penelitian ini adalah teknik triangulasi. Analisis data yang digunakan dalam penelitian mengacu pada teknik analisis Miles dan Huberman yang dilakukan melalui 3 komponen, yaitu reduksi data, penyajian data, dan penarikan kesimpulan.

Prosedur penelitian menggunakan model Kemmis dan Mc Taggart yang tiap siklus terdiri dari empat tahap, yaitu 1) perencanaan: berdasarkan hasil identifikasi masalah dari kegiatan observasi yang telah dilakukan sebelumnya, solusi yang dapat digunakan adalah dengan penerapan model guided inquiry learning dipadu dengan concept map untuk meningkatkan kemampuan berpikir analitis siswa. Tahap ini dilakukan penyusunan silabus, penyusunan skenario pembelajaran, dan LKS. Instrumen yang digunakan dalam penelitian juga disiapkan seperti soal tes, lembar observasi, dan pedoman wawancara; 2) pelaksanaan: implementasi dari tindakan yang telah direncanakan, yaitu penerapan model guided inquiry learning dipadu dengan concept map. Pelaksanaan tindakan diwujudkan dalam RPP; 3) Observasi: observasi dilakukan selama berlangsungnya proses pembelajaran. Observasi berupa kegiatan pengamatan, pencatatan, dan dokumentasi kegiatan selama pembelajaran. Observasi juga dilakukan pada keterlaksanaan sintaks model guided inquiry learning dipadu dengan concept map; dan 4) refleksi: kegiatan menganalisis dan membuat kesimpulan berdasarkan pelaksanaan, perbaikan pembelajaran dan hasil pengamatan oleh observer. Hasil observasi dianalisis untuk memperoleh gambaran dari tindakan yang telah dilakukan, hal yang perlu diperbaiki dan hal yang harus menjadi perhatian pada tindakan berikutnya. Target pencapaian pada penelitian dengan model guided inquiry learning dipadu dengan concept map ini adalah kemampuan berpikir analitis sebesar $60 \%$. 


\section{HASIL DAN PEMBAHASAN}

Penelitian dilakukan dengan tujuan untuk mengetahui peningkatan kemampuan berpikir analitis siswa melalui penerapan model guided inquiry learning yang dipadu dengan concept map serta mengetahui bagaimana proses peningkatannya. Data hasil penelitian yang dilakukan selama kegiatan pembelajaran pada tiap siklus menunjukkan terjadinya peningkatan kemampuan berpikir analitis siswa yang disajikan pada Tabel 1 dan Gambar 1.

Tabel 1. Peningkatan Persentase Kemampuan Berpikir Analitis pada Pra Siklus, Siklus I, Siklus II, dan Siklus III

\begin{tabular}{lcccc}
\hline \multirow{2}{*}{ Aspek } & \multicolumn{4}{c}{ Capaian Persentase (\%) } \\
\cline { 2 - 5 } & $\begin{array}{c}\text { Pra } \\
\text { Siklus }\end{array}$ & $\begin{array}{c}\text { Siklus } \\
\text { I }\end{array}$ & $\begin{array}{c}\text { Siklus } \\
\text { II }\end{array}$ & $\begin{array}{c}\text { Siklus } \\
\text { III }\end{array}$ \\
\hline Memilah & 33,09 & 36,03 & 73,16 & 56,99 \\
Mengorganisasi & 47,79 & 63,97 & 66,54 & 71,69 \\
Mengatribusi & 41,18 & 44,49 & 39,71 & 54,04 \\
Total & 40,69 & 48,16 & 59,80 & 60,91 \\
\hline
\end{tabular}

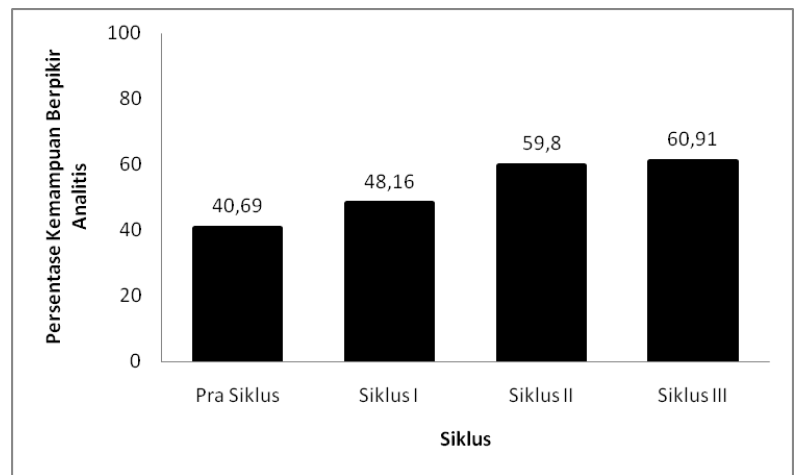

Gambar 1. Diagram Peningkatan Kemampuan Berpikir Analitis Siswa pada Pra Siklus, Siklus I, Siklus II, dan Siklus III

Kemampuan berpikir analitis mengalami peningkatan setiap siklusnya. Pada Pra Siklus persentase capaian yang diperoleh sebesar 40,69\%; kemudian untuk Siklus I meningkat menjadi 48,16\%; Siklus II meningkat kembali menjadi 59,80\%; dan Siklus III meningkat menjadi $60,91 \%$. Kemampuan berpikir analitis yang terdiri dari tiga aspek, yaitu memilah, mengorganisasi dan mengatribusi. Persentase capaian peningkatan setiap aspek kemampuan berpikir analitis disajikan pada Gambar 2.

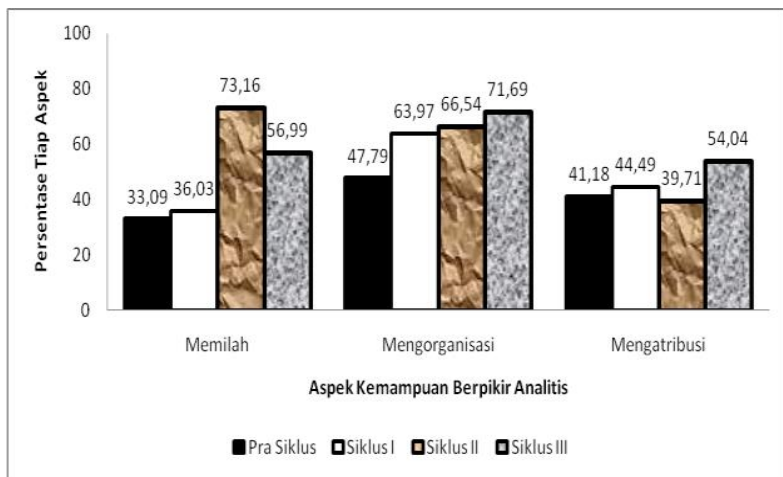

Gambar 2. Peningkatan Persentase Capaian Setiap Aspek Kemampuan Berpikir Analitis Siswa pada Pra Siklus, Siklus I, Siklus II, dan Siklus III

Peningkatan yang terjadi merupakan peran dan model guided inquiry learning yang diterapkan. Penerapan model guided inquiry learning dipadu concept map dilakukan dengan cara siswa diberi kesempatan untuk melakukan observasi, penelitian dan eksperimen berdasarkan masalah yang disajikan oleh guru, mengkaji literatur serta melakukan diskusi dengan teman satu kelompok, kemudian menuliskan konsep dan hasil observasi dalam bentuk concept map. Concept map dilakukan pada sintaks guided inquiry learning, yaitu pada sintaks mengumpulkan dan menganalisis data. Guru juga memberikan contoh concept map ketika siswa mengajukan pertanyaan dan pernyataan kemudian menuliskannya dalam bentuk concept map.

Proses sains seperti siklus inkuiri mampu mengembangkan kemampuan berpikir, salah satunya adalah kemampuan berpikir anaitis (Diraksa \& Termtachatipong, 2009). Menurut Sayekti, et al. (2012), inkuiri terbimbing memberikan kesempatan berpikir bagi siswa dan juga memberikan kesempatan siswa untuk mengembangkan metode ilmiah. Hale \& Mullen (2009) menyatakan bahwa salah satu tujuan dari pembelajaran guided inquiry adalah mengembangkan kemampuan orientasi proses seperti pemecahan masalah, berpikir kritis dan analitis serta komunikasi oral dan tertulis. Dengan kata lain, kemampuan berpikir analitis dapat dikembangkan melalui pembelajaran inkuiri yang dibimbing oleh guru. Pembelajaran inkuiri membantu siswa untuk mengembangkan tanggung jawab individu, metode kognitif, menulis laporan, pemecahan masalah dan kemampuan pemahaman.

Penulisan concept map dalam proses pembelajaran juga ikut berperan dalam meningkatkan kemampuan berpikir analitis. Menurut Chabeli (2010), concept map mampu membantu siswa untuk mengorganisasi dan menghubungkan informasi yang mereka tahu dengan pengetahuan baru. Siswa yang 
belum mempunyai pengalaman terkait concept map akan mengalami kesulitan dalam mengorganisasi konsep dan menyusun hubungan secara sistematis (Areesophonpichet, 2013).

Keseluruhan tahapan model guided inquiry learning yang dipadu dengan concept map membantu siswa dalam mengasah kemampuan berpikir analitis. Sejalan dengan pendapat Cuevas et al. dalam Nuangchalerm (2009) bahwa siswa berkolaborasi dengan temannya, berpikir secara mendalam tentang konsep yang kompleks, menghubungkan konten ilmu pengetahuan ke dalam kehidupan dan regulasi diri pada seluruh tahapan inkuiri.

\section{KESIMPULAN DAN SARAN}

Berdasarkan hasil penelitian dapat disimpulkan bahwa penerapan model guided inquiry learning dipadu dengan concept map dapat meningkatkan kemampuan berpikir analitis siswa kelas X-6 SMA Negeri Kebakkramat. Meningkatnya kemampuan berpikir analitis siswa dikarenakan siswa diberi kesempatan untuk melakukan observasi, penelitian dan eksperimen berdasarkan masalah yang disajikan oleh guru, mengkaji literatur serta melakukan diskusi dengan teman satu kelompok, kemudian menuliskan konsep dan hasil observasi dalam bentuk concept map. Perlu diadakan penelitian sejenis dengan model pembelajaran baru yang lebih efektif dan efisien untuk meningkatkan kemampuan berpikir analitis.

\section{DAFTAR PUSTAKA}

Amri, S. \& Ahmadi, I. K. (2010). Proses Pembelajaran Kreatif dan Inovatif dalam Kelas. Jakarta: Prestasi Pustakaraya.

Anderson, L. W. \& Krathwohl, D. R. (2010). Kerangka Landasan Untuk Pembelajaran, Pengajaran, dan Asesmen: Revisi Taksonomi Pendidikan Bloom. Yogyakarta: Pustaka Pelajar.

Areesophonpichet. (2013). A Development of Analytical Thinking Skills of Graduate Students by Using Concept Mapping. The Asian Conference on Education (hal. 1-15). Osaka: The International Academic Forum.

Chabeli, M. (2010). Concept-Mapping As a Teaching Method to Facilitate Critical Thinking in Nursing Edcation: A Review of the Literature. Journal of Interdisciplinary Health Sciences , 1-7.

Diraksa, T. \& Termtachatipong. (2009). The Development of Grade 10 Students' Analytical Thinking Ability and Learning Achievement About Heredity by Using Constructivist Theory Teaching Strategies Based on Underhill Approach. 1-8.

Hale, D. \& Mullen, L.G. (2009). Designing ProcessOriented Guided-Inquiry Activities: A New
Innovation for Marketing Classes. Marketing Education Review , 73-80.

Nuangchalerm, P. (2009). Cognitive Development, Analytical Thinking and Learning Satisfaction of Second Grade Students Learned trough Inquirybased Learning. Asian Social Science , 82-87.

Nurtafita, N. (2011). Pengaruh Pembelajaran Inkuiri Terbimbing Terhadap keterampilan Proses Sains Siswa Pada Konsep Kalor. Jakarta: Skripsi S1 UIN Syarif Hidayatullah.

Purwito, H., Handoyo, B., Neilna, Y. E. (2013). Model Pembelajaran Group Investigation (GI) Terhadap Kemampuan Berpikir Analisis. Jurnal Pendidikan Geografi Universitas Negeri Malang, 2(1): 1-9.

Rohana, Hartono, Yusuf, \& Purwoko. (2009). Penggunaan Peta Konsep Dalam Pembelajaran Statistika Dasar Di Program Studi Pendidikan Matematika FKIP Universitas PGRI Palembang. Jurnal Pendidikan Matematika, 3(2): 92-102.

Sayekti, I.C., Sarwanto, \& Suparmi. (2012). Pembelajaran IPA Menggunakan Pendekatan Inkuiri Terbimbing Melalui Metode Eksperimen dan Demonstrasi Ditinjau dari Kemampuan Analisis dan Sikap Ilmiah Siswa. Jurnal Inkuiri, 142-153.

Sujana, A. (2009). Peta Konsep (Concept Maps) dalam Pembelajaran Sains: Studi Kelas V Sekolah Dasar (SD). Jurnal Pendidikan Dasar, 12.

Warsono \& Hariyanto. (2013). Pembelajaran Aktif: Teori dan Asesmen. Bandung: PT Remaja Rosdakarya. 